\title{
RESEARCH PAPER \\ Nutritional value of Brachiarias and forage legumes in the humid tropics of Ecuador
}

\author{
Diana G. Balseca ${ }^{1}$, Eugenia G. Cienfuegos ${ }^{1,2}$, Hilda B. López ${ }^{1}$, Hernán P. \\ Guevara $^{3}$ and Juan C. Martínez ${ }^{2}$ \\ ${ }^{1}$ Centro de Investigación, Universidad Tecnológica Equinoccial. Extensión Santo Domingo, km 4.5 Vía \\ Chone, Santo Domingo de los Tsáchilas, Ecuador. \\ ${ }^{2}$ Universidad Autónoma de Tamaulipas, Facultad de Ingeniería y Ciencias. Centro Universitario Adolfo \\ López Mateos. CP. 87149, Cd. Victoria, Tamaulipas, Mexico. \\ ${ }^{3}$ Escuela Superior Politécnica de Chimborazo. Panamericana Sur km 1 1/2, Riobamba, Ecuador.
}

\begin{abstract}
D.G. Balseca, E.G. Cienfuegos, H.B. López, H.P. Guevara, and J.C. Martínez. 2015. Nutritional value of Brachiarias and forage legumes in the humid tropics from Ecuador. Cien. Inv. Agr. 42(1): 57-63. This research evaluated the nutritional value of five varieties of Brachiarias: $B$. decumbens Stapf; $B$. brizantha Marandú; B. brizantha Piatá; $B$. brizantha Xaraés; and Mulato II $[B$. ruziziensis $\times$ B. brizantha $]$ ). The Brachiarias were combined at different inclusion rates $(0,10$ and $15 \%)$ with two tropical forage legume species (Centrosema pubescens and Cajanus cajan, ECV22). The samples were collected at the experimental farm, The Oasis, a property of the Universidad Tecnológica Equinoccial (Ecuador), with $42 \mathrm{~d}$ of regrowth for the Brachiarias and $150 \mathrm{~d}$ for the legumes in the dry season. The proximate analysis and the Van Soest procedure were performed in the laboratory of food science and animal nutrition of the Escuela Superior Politécnica de Chimborazo (Ecuador). The in situ digestibility of dry matter (ISDDM) was assessed in three Holstein cows $(560 \pm 23 \mathrm{~kg})$ with ruminal cannula. The proximal and Van Soest variables were analyzed with a complete randomized design, and for the variable ISDDM, a randomized block design was used. Significant differences for ISDDM $(\mathrm{P} \leq 0.05)$ between the Brachiaria varieties were found, with the highest percentages for the cv. B. decumbens Stapf and B. brizantha Marandú (63.9 and 63.2\%, respectively). The diet with $10 \%$ C. cajan had average percentages of $\mathrm{CP}, \mathrm{NDF}$ and $\mathrm{ADF}$ of $8.7,70.7$ and $47.6 \%$, respectively, for all the Brachiaria varieties used in the study. It was found that diets with $B$. decumbens and $B$. Mulato II plus $10 \%$ of $C$. cajan were the best in terms of CP, NDF, ADF and ISDDM $(9.3,70.5,46.4$ and $64.1 \%$ and $8.6,69.9,50.3$ and $63.5 \%$, respectively). The results of this research showed that the value of $\mathrm{CP}$ meets the minimum requirements of nitrogen in the ration and that the ISDDM, DM, CF, NDF, $\mathrm{ADF}$ and $\mathrm{ADL}$ values are within the ranges reported for the genus Brachiaria.
\end{abstract}

Key words: Brachiaria, Cajanus cajan, Centrosema pubescens, digestibility, grasses, legumes, nutritional value.

\section{Introduction}

The extensive and intensive production systems of grasses that are found in tropical and subtropical

Received November 26, 2014. Accepted March 18, 2015. Corresponding author: jmartinez@uat.edu.mx regions produce the primary, inexpensive food for the ruminants that are the main source of animal protein for the human population (Velásquez et al., 2010).

The Brachiaria are forage plants that are widely known and used in tropical America because 
they possess excellent forage qualities that allow them to substantially improve the indices of productive systems (Cuadrado et al., 2004). Their characteristics are favorable to adaptation to the most difficult environmental conditions and to a variety of cultivation and management systems. There are a wide number of varieties or genotypes of Brachiaria that can well tolerate grazing, different levels of humidity, and different levels of soil acidity or salinity and that have an acceptable nutritional value when compared with legumes (Avellaneda et al., 2008; Rincon et al., 2008).

The capacity of a pasture to provide the nutritional requirements for the maintenance, growth and reproduction of grazing animals is known as the nutritional value of the plant. In general terms, the nutritional value of forage species is the result of intrinsic plant factors, such as chemical composition, digestibility, environmental factors, as well as factors characteristic of the animal and the interaction between pastures, animals and the environment (Barahona and Sanchez, 2005; Pirela, 2005).

To compare the nutritional value of the food from the perspective of the ruminants' nutritional needs and to determine if the nutritional requirements of the animals are met, it is necessary to evaluate the digestibility (the capacity of a nutrient to be assimilated by an animal). This is because not all the food that is eaten is assimilated by the organism; in fact, part of it is removed, mainly by slop, which represents the greatest nutritional loss in the process of energy use or incomplete digestion (Rodriguez et al., 2007).

The incorporation of legumes into pasture for beef production has been reported to provide numerous benefits for the soil-plant-animal trilogy: for the soil, the legumes improve the mineral composition and guarantee the capacity to fix atmospheric nitrogen; for plants, these species increase production and the protein quality of associated grasses and improve air quality; for the animals, they contribute to productivity by increasing the edible biomass, the voluntary intake, the digestibility of the forage and the incorporation of vitamins A, B, C and D in the diet (Diaz et al., 2012; Paciullo et al., 2014).

The objective of this research was to evaluate the nutritional value of mixtures consisting of five varieties of Brachiaria combined with different inclusion rates of two species of tropical forage legumes.

\section{Materials and methods}

The agronomic material was established during 2012 on the experimental farm, The Oasis, of the Escuela de Ingenieria Agricola Universidad Tecnologica Equinoccial, Campus Santo Domingo, Ecuador. The experimental site is located at $00^{\circ}$ $13^{\prime} 37^{\prime \prime} \mathrm{LS}$ and $79^{\circ} 15^{\prime} 04^{\prime}$ ' LW; the prevailing climate is tropical humid with an annual average temperature of $23.5^{\circ} \mathrm{C}$ and an annual rainfall of 2,600 to $2,800 \mathrm{~mm}$ distributed in the rainy months with six dry months. The laboratory analyses (proximal and Van Soest) were conducted in the Laboratory of Food Science and Animal Nutrition of the Escuela Superior Politecnica de Chimborazo, Ecuador.

The experimental material was $B$. decumbens Stapf; B. brizantha Marandu; B. brizantha Piata; B. brizantha Xaraes; and Mulato II (B. ruziziensis $\times B$. brizantha). The plants were set in plots of $4 \times 4 \mathrm{~m}$ distributed randomly in three replicates, and samples were taken during the first year of establishment at 42 days of regrowth in the dry season. The two species of legumes in the study, Centrosema pubescens and Cajanus cajan (ECV22), were obtained in the first year of establishment. They were distributed randomly in $3 \times 3 \mathrm{~m}$ plots in three replicates, and samples were taken at 150 days of growth in the dry season.

Thirty experimental mixtures were made incorporating combinations of the five varieties of Brachiaria with the three percentages of inclusion $(0,10$, and 
$15 \%$ ) of each legume (C. pubescens and C. cajan). The in situ dry matter digestibility (ISDMD) was determined in three Holstein cows with an average weight of $560 \pm 23 \mathrm{~kg}$ that were supplied with cannula rumen (Giraldo, 1996) and were kept in the Centro Experimental Tunshi the Escuela Superior Politecnica de Chimborazo, Ecuador. The bromatological determinations of dry-matter (DM), ash (A), ether extract (EE), crude protein (CP), and crude fiber (CF) were in accordance with the official methods of analysis (AOAC, 1990); neutral detergent fiber (NDF), acid detergent fiber (ADF) and acid detergent lignin (ADL) were measured in accordance with Van Soest (1994).

A random block design corresponding to a factorial design $(5 \times 2 \times 3)$ where factor $\mathrm{A}=$ varieties of Brachiaria, factor $\mathrm{B}=$ proportion of legumes, and factor $\mathrm{C}=$ leguminous type was established to evaluate the percentage of in situ digestibility of dry matter (ISDDM):

$$
\begin{gathered}
Y_{i j k l m}=\mu+\mathrm{B}_{i}+\underset{j}{G_{j}+I_{k}+L_{l}+(G I)_{j k}+(G L)_{j l}+} \\
(I L)_{k l}+\varepsilon_{i j k l m}
\end{gathered}
$$

where $Y_{i j k l m}=$ dependent variable; $\mu=$ general mean; $\mathrm{B}_{i}=$ effect of block (cattle with rumen fistula); $G_{j}=$ the effect of the grass; $I_{k}=$ percentage of leguminous inclusion; $L_{l}=$ and leguminous type effect; $(G I)_{j k}=$ interaction of the grass and percentage legume inclusion; $(G L)_{j l}=$ interaction of the grass and legume type; $(I L)_{k l}=$ interaction of the legume inclusion with legume type; and $\varepsilon_{i j k l m}=$ experimental error.

A random block design corresponding to a factorial design $(5 \times 2 \times 3)$ where factor $A=$ varieties of Brachiaria; factor $\mathrm{B}=$ proportion of leguminous inclusion; and factor $\mathrm{C}=$ leguminous type, was used to evaluate the percentage of dry matter (DM), crude fiber (CF), crude protein (CP), neutral detergent fiber (NDF), acid detergent fiber (ADF) and acid detergent lignin (ADL):

$$
\begin{aligned}
Y_{j k l m}=\mu+G_{j}+I_{k}+ & L_{l}+(G I)_{j k}+(G L)_{j l}+(I L)_{k l} \\
& +\varepsilon_{j k l m}
\end{aligned}
$$

where $Y_{j k l m}=$ dependent variable; $\mu=$ general mean; $G_{j}=$ the effect of the grass; $I_{k}=$ percentage of leguminous inclusion; $L_{l}=$ leguminous type effect; $(G I)_{j k}=$ interaction of the grass and percentage legume inclusion; $(G L)_{j l}=$ interaction of the grass and legume type; $(I L)_{k l}=$ interaction of the legume inclusion with legume type; and $\varepsilon_{j k l m}=$ experimental error.

For both designs, the Tukey multiple comparisons test, with a significance level of $\mathrm{P} \leq 0.05$, was applied using the SAS V.8 program (SAS Institute, Cary, NC, USA, 2001).

\section{Results and discussion}

In the present experiment, the overall mean ISDDM for the varieties of Brachiaria was $62.0 \%$, and there was no treatment effect $(\mathrm{P}>0.05)$. This result is different from that reported by Moreira et al. (2013) for the differences observed in the in vitro digestibility of the dry matter (IVDDM) of different Brachiaria varieties and grazing systems. Similarly, Quintino et al. (2013) found that the age of the plant affected the IVDDM of $B$. brizantha $\mathrm{cv}$. BRS and B. brizantha. Digestibility depends mostly on the nutritional composition of the grass-legume mixture; the estimated values of the apparent digestibility of the fractions corresponding to proteins and lipids, without including the contributions of endogenous compounds of the same type, are always lower than the true digestibility coefficients (Ramirez et al., 2009). The utility of working with ruminants is that the contribution of endogenous nitrogen is approximately 0.5 to $0.6 \mathrm{~g}$ per $100 \mathrm{~g} \mathrm{DM}^{-1}$ consumed, so the coefficients of apparent digestibility in rations containing less than $4 \%$ protein, are negative (Giraldo et al., 2007).

The ISDMDs according to the varieties of Brachiarias are presented in Table 1 . While $B$. decumbens and $B$. brizantha Marandu are the species that presented the highest values for ISDMD (63.2 and $63.7 \%$, respectively); these differences were 
Table 1. In situ digestibility of dry matter (ISDDM), dry matter (DM), crude fiber (CF), crude protein (CP), neutral detergent fiber (NDF), acid detergent fiber (ADF) and acid detergent lignin (ADL) for different varieties of Brachiaria in the humid tropics of Ecuador.

\begin{tabular}{|c|c|c|c|c|c|c|c|}
\hline \multirow[b]{3}{*}{ Varieties } & \multicolumn{4}{|c|}{ Proximate Analysis } & \multicolumn{3}{|c|}{ Van Soest } \\
\hline & ISDDM & DM & $\mathrm{CF}$ & $\mathrm{CP}$ & NDF & $\mathrm{ADF}$ & $\mathrm{ADL}$ \\
\hline & Mean (SD) & Mean (SD) & Mean (SD) & Mean (SD) & Mean (SD) & Mean (SD) & Mean (SD) \\
\hline $\begin{array}{l}\text { B. decumbens } \\
\text { Stapf }\end{array}$ & $63.2(6.2)$ & $22.7(0.7) b c$ & $42.9(2.4) \mathrm{ab}$ & $9.1(0.9) \mathrm{a}$ & $71.3(1.6) b$ & $46.2(0.7) \mathrm{d}$ & $17.6(0.1) b$ \\
\hline $\begin{array}{l}\text { B. brizantha } \\
\text { Marandú }\end{array}$ & $63.7(9.6)$ & $23.4(0.7) a b$ & $41.9(3.1) b$ & $8.3(1.2) \mathrm{ab}$ & $71.7(0.6) b$ & $47.6(0.7) \mathrm{c}$ & $19.9(1.9) \mathrm{ab}$ \\
\hline $\begin{array}{l}\text { Mulato II ( } B \text {. } \\
\text { ruziziensis } \mathrm{x} \\
\text { B. brizantha) }\end{array}$ & $62.4(4.9)$ & $23.2(0.4) a b$ & $45.4(3.3) \mathrm{a}$ & $7.9(0.9) b$ & $70.6(0.8) b$ & $49.4(1.0) \mathrm{b}$ & $18.9(3.2) \mathrm{ab}$ \\
\hline $\begin{array}{l}\text { B. brizantha } \\
\text { Piatá }\end{array}$ & $60.8(5.5)$ & $23.7(1.1) \mathrm{a}$ & $43.2(1.2) \mathrm{ab}$ & $7.7(0.6) b$ & $73.9(2.9) \mathrm{a}$ & $51.0(1.9) \mathrm{a}$ & $20.6(1.0) \mathrm{a}$ \\
\hline $\begin{array}{l}\text { B. brizantha } \\
\text { Xaraés }\end{array}$ & $60.0(6.6)$ & $21.9(0.7) \mathrm{c}$ & $41.1(1.1) b$ & $8.3(1.2) \mathrm{ab}$ & $70.4(1.9) \mathrm{b}$ & $48.9(0.9) \mathrm{bc}$ & $18.3(2.7) a b$ \\
\hline
\end{tabular}

$\mathrm{a}, \mathrm{b}, \mathrm{c}$ in the columns indicate significantly different results according to the Tukey test $\mathrm{P} \leq 0.05 ; \mathrm{SD}=$ standard deviation.

not significant $(\mathrm{P}>0.05)$. However, Avellaneda et al. (2008) studied the ISDDM of varieties of Brachiarias at different days of cultivation. While some age- and species-related variability was noted, no significant differences in digestibility for the different plant ages $(\mathrm{P}>0.05)$ was found. Moreira et al. (2013) found no differences in the ISDDM for the varieties Xaraes and Marandu ISDMD. Ramirez et al. (2009) found that the ISDDM was affected $(\mathrm{P} \leq 0.05)$ by the age of the grasses $(B$. decumbens cv. Basilisk and hybrid Brachiaria cv. Mulatto). All double interactions for all the factors for ISDDM were non-significant $(\mathrm{P}>0.05)$.

In addition, $\mathrm{DM}, \mathrm{CF}$ and $\mathrm{CP}$ were 23.0, 42.9 and $8.3 \%$, respectively, and it was observed that these values were affected $(\mathrm{P} \leq 0.05)$ by the variety of Brachiarias. Table 1 shows that $B$. decumbens presented the highest percentage of $\mathrm{CP}(9.1 \%)$, while $B$. brizantha only reached $7.7 \%$ of $\mathrm{CP}(\mathrm{P} \leq 0.05)$. Some authors report that in the fibrous diets ruminants consume, the volume of the DM and the amount of time that the DM remains in the rumen affect consumption; consumption, in turn, has a negative relationship with digestibility, which is controlled by the animal's energy requirements (Barahona and Sanchez, 2005). However, Avellaneda et al. (2008) observed that the DM and CP content were not modified ( $\mathrm{P}>0.05)$ by the variety of Brachiaria, which is most likely because the DM and CP are more related to climatic variations and the age of the pasture growth The main component of the fodder that influences digestibility and consumption is the cell wall, the thickness of which is inversely proportional to the digestibility and voluntary intake. The reduction in digestibility is explained because the more easily digestible nutrients are contained in the cell cytoplasm, while the less digestible components are found in the cell wall (Morales et al., 2013).

For fiber, the NDF, ADF and ADL fractions were $71.6,48.6$ and $19.1 \%$, respectively. As in the previous cases (varieties), the treatment affected $(\mathrm{P} \leq 0.05)$ the percentages of fibers. Slightly lower results were reported by Cuadrado et al. (2004) in a trial conducted in Colombia that studied the effect of the time and the varieties $B$. decumbens and $B$. brizantha. The study reported values of 69.8 and $67.6 \%$, respectively, for NDF and 34.1 and $40.6 \%$, respectively, for ADF using these varieties. Another study reported that the ADF is inversely proportional to the digestibility, while the NDF is directly related to the ability to forage and to the ideal volume in the gastrointestinal tract and consumption of the MS (Cruz and Sanchez, 2000). 
Similarly, the percentage of ADL (lignification of the cell wall of plants) is inversely related to the degradability of DM and, consequently, a low IVDMD and ISDMD (Ramírez et al., 2002). These results lead us to suggest that $B$. decumbens and $B$. brizantha offered alone could be an option in a livestock production system.

Finally, the percentages of ISDMD, DM, CF, CP, NDF, ADF and ADL were 62.3, 22.8, 43.4, 8.4, $71.3,48.5$ and $19.0 \%$, respectively. Table 2 presents the results for the level of legume included $(0,10$, and $15 \%$ ) and the leguminous type (C. pubescens and $C$. cajan), which did not affect the ISDMD, $\mathrm{DM}, \mathrm{CF}, \mathrm{CP}, \mathrm{NDF}, \mathrm{ADF}$ or ADL $(\mathrm{P}>0.05)$. Results contrary to those in the present study were reported by Morales et al. (2013), who observed that the nutritional quality of pastures showed differences $(\mathrm{P} \leq 0.04)$ when bird foot clover was included (Lotus uliginosus). This association was apparent in terms of voluntary forage intake $(\mathrm{P} \leq 0.05)$ and milk production $(\mathrm{P} \leq 0.05)$.

Because tropical grasses have low nutritional value, one management strategy is to include legumes in the diets of animals or to include grasses associated with legumes in pastures for direct consumption during grazing (protein banks). This is because legumes have higher nutritional value than grasses, and rations that combine grasses and legumes are consumed in larger quantities by animals than diets containing only grasses, as reflected by increased weight gain (Diaz et al., 2012). Some studies have reported that species of leguminous trees and shrubs used as supplements in the diets of ruminants improve the nutritive value of the pasture forage, increase voluntary consumption, reduce the nutritional stress in animals and can increase the protein:energy relationship of the rations (Galindo et al., 2005). In general, the greater the content of NDF (cell wall) of one fodder, the lower its digestibility. However, this relationship does not always hold because cell wall digestibility depends on the degree of lignification.

The results of this research showed that the value of $\mathrm{CP}$ meets the minimum requirements of nitrogen in the ration and that the ISDMD, DM, CF, NDF, $\mathrm{ADF}$ and $\mathrm{ADL}$ are within the ranges reported for the genus Brachiaria. However, the inclusion of legumes (C. pubescens and C. cajan) provided no improvement in the quality of rations composed of different varieties of Brachiaria. All double interactions for all the factors and variables were non-significant effects $(\mathrm{P}>0.05)$.

Table 2. In situ digestibility of dry matter (ISDDM), dry matter (DM), crude fiber (CF), crude protein (CP), neutral detergent fiber (NDF), acid detergent fiber (ADF) and acid detergent lignin (ADL) as a result of the inclusion of different proportions of Centrosema pubescens and Cajanus cajan of Brachiaria in the humid tropics of Ecuador.

\begin{tabular}{|c|c|c|c|c|c|}
\hline & \multirow[b]{2}{*}{ Control $(0 \%)$} & \multicolumn{2}{|c|}{ Centrosema pubescens } & \multicolumn{2}{|c|}{ Cajanus cajan } \\
\hline & & $(10 \%)$ & $(15 \%)$ & $(10 \%)$ & $(15 \%)$ \\
\hline & Mean(SD) & Mean(SD) & $\operatorname{Mean}(\mathrm{SD})$ & $\operatorname{Mean}(\mathrm{SD})$ & Mean(SD) \\
\hline ISDDM (\%) & $61.5(7.3)$ & $65.3(5.4)$ & $61.1(6.0)$ & $62.5(6.6)$ & $61.0(7.3)$ \\
\hline DM $(\%)$ & $23.6(0.9)$ & $22.7(0.9)$ & $23.1(0.8)$ & $22.6(0.7)$ & $22.2(0.9)$ \\
\hline $\mathrm{CF}(\%)$ & $40.3(1.5)$ & $44.5(3.1)$ & $44.1(2.1)$ & $44.6(2.2)$ & $43.6(1.7)$ \\
\hline $\mathrm{CP}(\%)$ & $7.4(0.4)$ & $7.8(0.5)$ & $8.3(0.7)$ & $8.7(1.0)$ & $9.9(0.9)$ \\
\hline NDF (\%) & $72.9(2.6)$ & $71.3(1.3)$ & $71.0(1.7)$ & $70.7(1.2)$ & $70.8(1.9)$ \\
\hline $\operatorname{ADF}(\%)$ & $49.4(2.4)$ & $48.9(1.9)$ & $48.7(1.7)$ & $47.6(1.3)$ & $47.8(1.5)$ \\
\hline $\operatorname{ADL}(\%)$ & $19.2(1.5)$ & $19.1(2.1)$ & $19.7(3.8)$ & $17.7(2.8)$ & $19.5(1.2)$ \\
\hline
\end{tabular}

$\mathrm{SD}=$ standard deviation . 


\section{Acknowledgements}

The author extends thanks to the following institutions that facilitated this research: the Universidad Tecnologica Equinoccial (UTE) in Ecuador for the funding to conduct this research, the Escuela
Superior Politecnica del Chimborazo (ESPOCH) in Ecuador for technical support in the Laboratory of Animal Nutrition, and the Universidad Autonoma de Tamaulipas (UAT) in Mexico for its contribution of technical knowledge about sheep breeding in the wet tropics.

\section{Resumen}

D.G. Balseca, E.G. Cienfuegos, H.B. López, H.P. Guevara y J.C. Martínez. 2015. Valor nutritivo de Brachiarias y leguminosas forrajeras en el trópico húmedo de Ecuador. Cien. Inv. Agr. 42(1): 57-63. En la presente investigación se evaluó el valor nutritivo de cinco variedades de Brachiarias (B. decumbens Stapf; B. brizantha Marandú; B. brizantha Piatá; $B$. brizantha Xaraés; y Mulato II [B. ruziziensis x B. brizantha]), combinadas con diferentes porcentajes de inclusión $(0,10$ y $15 \%)$ de dos leguminosas forrajeras tropicales (Centrosema pubescens y Cajanus cajan, ECV22). Las muestras fueron colectadas en la granja experimental "El Oasis" de la Universidad Tecnológica Equinoccial a una edad de rebrote para Brachiarias de 42 d y para leguminosas de 150 d en época seca. Los análisis proximal y de Van Soest se realizaron en el laboratorio de bromatología y nutrición animal de la Escuela Superior Politécnica de Chimborazo (ESPOCH), la digestibilidad in situ de la materia seca (DISMS) se evaluó en tres vacas Holstein $(560 \pm 23 \mathrm{~kg})$ con cánula ruminal. Las variables del análisis proximal y Van Soest fueron analizadas con un modelo completamente al azar y para la variable DISMS con un diseño de bloques al azar. Se encontraron diferencias $(\mathrm{P} \leq 0,05)$ entre variedades para DISMS con los porcentajes más altos para las $B$. decumbens Stapf y B. brizantha Marandú (63,9 y 63,2\%). La mezcla con $10 \%$ de $C$. cajan tuvo porcentajes de PC, FDN y FDA de 8,$7 ; 70,7$ y 47,6\%, respectivamente en promedio para todas las variedades de Brachiaria. Se encontró que las dietas con $B$. decumbens Stapf y Mulato II más el 10\% C. cajan fueron las mejores en términos de PC, FDN, FDA y DISMS (9,3; 70,5; 46,4 y 64,1\% y 8,6; 69,9; 50,3 y $63,5 \%$, respectivamente). Los resultados de esta investigación mostraron que el valor de PC satisfice las necesidades mínimas de nitrógeno en la ración y que la DISMS, MS, FC, FDN, FDA y LDA están dentro de los rangos reportados para el género Brachiaria.

Palabras clave: Brachiaria, Cajanus cajan, Centrosema pubescens, digestibilidad, gramíneas, leguminosas, valor nutritivo.

\section{References}

AOAC-Official Methods of Analysis. 1990. 15th Edition. Association of Official Analytical Chemists, Inc. Arlington, Virginia, USA. 771 pp. Avellaneda, C.J., F.G. Cabezas, G.Z. Quintana, R.M. Luna, O.V. Montañez, I.G. Espinoza, S.M. Zambrano, D.G. Romero, J.R. Vanegas, and E.M. Pinargote. 2008. Comportamiento agronómico y composición química de tres variedades de $\mathrm{Bra}$ - chiaria en diferentes edades de cosecha. Ciencia y Tecnología 1:87-94.

Barahona, R.R., and S.P. Sánchez. 2005. Limitaciones físicas y químicas de la digestibilidad de pastos tropicales y estrategias para aumentarla. Revista Corpoica: Ciencia y Tecnología Agropecuarias 6:69-82.

Cruz, M., and J. Sánchez. 2000. La fibra en la alimentación del ganado lechero. Nutrición Animal Tropical 6:39-74. 
Cuadrado, H., L. Torregroza, and N. Jiménez. 2004. Comparación bajo pastoreo con bovinos machos de ceba de cuatro especies de gramíneas del género Brachiaria. MVZ Córdoba 9:438-443.

Díaz, A., P. Martín, E. Castillo, and J. Hernández. 2012. Suplementación de añojos Charolais de Cuba en pastoreo de asociación múltiple de leguminosas herbáceas y gramíneas tropicales. Revista Cubana de Ciencia Agrícola 46:249-252.

Galindo, J., D. Delgado, and R. Pedraza. 2005. Impacto de los árboles, los arbustos y otras leguminosas en la ecología ruminal de animales que consumen dietas fibrosas. Pastos y Forrajes 28:59-68.

Giraldo, L., L. Gutiérrez, and C. Rúa. 2007. Comparación de dos técnicas in vitro e in situ para estimar la digestibilidad verdadera en varios forrajes tropicales. Revista Colombiana de Ciencias Pecuarias 20:269-279.

Giraldo, L.A. 1996. Estandarización de la técnica de la biodegradación ruminal in situ, para evaluar forrajes tropicales. Revista Colombiana de Ciencias Pecuarias 9(Suppl):59-63.

Morales, A., J. Leon, E. Cárdenas, G. Afanador, and J. Carulla. 2013. Composición química de la leche, digestibilidad in vitro de la materia seca y producción en vacas alimentadas con gramíneas solas o asociadas con Lotus uliginosus. Revista de la Facultad de Medicina Veterinaria y Zootecnia 60:32-48.

Moreira, J.F.M., K.A.P., Costa, E.C. Severiano, P.S. Epifânio, W.S. Crunivel, and K.C. Guimarães. 2013. Protein fraction and digestibility of maran$\mathrm{du}$, xaraes and campo grande grasses in monocropping and intercropping systems under different sowing methods. Acta Scientiarum. Animal Science 35:63-71.

Paciullo, D.S.C., M.F.A. Pires, L.J.M. Aroeira, M.J.F. Morenz, R.M. Maurício, C.A.M. Gomide, and S.R. Silveira. 2014. Sward characteristics and performance of dairy cows in organic grasslegume pastures shaded by tropical trees. Animal 8:1264-1271.
Pirela, M.F. 2005. Valor nutritivo de los pastos tropicales. In: González-Stagnaro, C. and E. Soto-Belloso (eds.). Manual de ganadería doble propósito. Ediciones Astro Data, S.A. Maracaibo-Venezuela. p. 283-290.

Quintino, A.C., J.G. de Abreu, R.G. de Almeida, M.C.M. Macedo, L.S. Cabral, and R.L. Galati. 2013. Production and nutritive value of piatã grass and hybrid sorghum at different cutting ages. Acta Scientiarum. Animal Science 35:243249.

Ramírez, R.O., G.L. Ramírez, and F.G. López. 2002. Factores estructurales de la pared celular del forraje que afectan su digestibilidad. Ciencia UANL 5:180-189.

Ramírez, J.L.R., M.E. Vega, I.L. Acosta, and D.A. Verdecia. 2009. Caracterización nutritiva de las especies Brachiaria decumbens e hibrido en un suelo fluvisol de Cuba. LRRD 21: Artículo \#23. Available online at: http://www.lrrd.org/lrrd21/2/ rami21023.htm (Website accessed: November 15, 2013).

Rincón, A.C., G.A.M. Ligarreto, and E. Garay. 2008. Producción de forraje en los pastos Brachiaria decumbens cv. Amargo y Brachiaria brizantha cv. Toledo, sometidos a tres frecuencias y a dos intensidades de defoliación en condiciones del Piedemonte llanero colombiano. Revista de la Facultad Nacional Agraria de Medellín 61:43364346.

Rodríguez, N.M., E. Oliveira Simões, and R. Guimarães-Júnior. 2007. Uso de indicadores para estimar consumo y digestibilidad de pasto. LIPE, lignina purificada y enriquecida. Revista Colombiana de Ciencias Pecuarias 20:518-525.

Van Soest, P. 1994. Nutrition ecology of the ruminant. Second Edition. Cornell University Press. 488 pp. Velásquez, P.A.T., T.T. Berchielli, R.A. Reis, A.R. Rivera, P.H.M. Dian, and I.A.M.A. Teixeira. 2010. Composição química, fracionamento de carboidratos e proteínas e digestibilidade in vitro de forrageiras tropicais em diferentes idades de corte ${ }^{1}$. Revista Brasileira de Zootecnia 39:1206-1213. 
